УДК 811.162.1:83’384

DOI: 10.37026/2520-6427-2019-99-3-105-108
Оксана КОЗІЦЬКА,

кандидатка філологічних наук, доцентка кафедри стилістики та культури украӥнської мови

Рівненського державного гуманітарного університету

\title{
ОСОБЛИВОСТІ ФУНКЦІОНУВАННЯ СУРЯДНИХ СПОЛУЧНИКІВ У ПРИЕДНУВАЛЬНИХ СТРУКТУРАХ
}

У статті розглянуто актуальні питання сьогодення щзодо функиіонування окремих сурядних сполучників (єднальної і протиставної семантики) в зоні приєднувальних семантико-синтаксичних відношень. Визначено типові позииії їхнього вживання в конфесійному стилі.

Ключові слова: приєднувальне речення, конфесійний стиль, багатокомпонентна приєднувальна структура, сурядні сполучники, складне речення.

В статье проанализированы основные аспекты функиионирования присоединительных конструкичй. Определена структурная и семантическая роль сочинительных союзов в присоединительной структуре. Определень основные позиции их употребления в конфессионном стиле.

Ключевые слова: присоединительное предложение, сложное многокомпонентное иелое, конфессионный стиль, сочинительные союзы, семантическая структура.

The research of problems of semantics in modern linguistics constantly attracts the attention of linguists, in particular to the questions of expressive syntax. In modern Ukrainian linguistics the problem of isolation and qualification of joining constructions remains. In linguistic literature, there is a lack of formal criteria for the delineation of the phenomena of parceling and joining, which leads to the identification of these concepts. The long discussions surrounding the nature of the connecting structures caused some discrepancies in their syntactic characteristics. Such structures are analyzed mainly on the material of artistic and journalistic texts; in texts of confessional style, the nature of such sentences was not explored.

In linguistics, two terms are used simultaneously «joining structure». Some linguists treat any dismemberment of the syntactic structure as a "parsed structure», other such sentences are traditionally called as joining, and parselling as a phenomenon of expressive syntax is identified or viewed within the framework of attachment .

In Ukrainian studies, two different approaches prevailed in interpreting this phenomenon of language.

1. Connection is considered to be a special kind of syntactic connection, when two syntactical units relate on the basis of the semantic-grammatical independence of the reference sentence and semantic and grammatical attraction to it of the connecting structure.
2. Joining is a «semantic-grammatical category that has its own semantics (value of additional message) and its own grammatical form of expression of this semantics (special conjunctions, connecting words)».

Supporting the views of $K$. Gorodenska, A. Zagnutka, N. Ivkova, V. Bogatko, L. Konyukhova and others. Ukrainian linguists, we believe that the joining structure clarifies, specifies, details or denotes one or more elements of the main sentence. The implementation of the semantic-syntactic connecting connection is carried out with the help of proper joining compounds, the isolation of which is associated with the distinction between the six types of semantic-syntactic relations, which transmit arbitrary connections. Means of expression of connecting semantic-syntactic relations can also act as arbitrary connectives of connecting and opposing semantics. For connects the connecting semantic-syntactic relations are transpositions.

Connective constructions with arbitrary connectives of connecting and opposing semantics are increasingly used in texts of confessional style to enhance language expression. This is completed in terms of content and grammatical expression. In direct language, such structures clearly demonstrate the process of sentence division. Joining expands syntactical, stylistic, and informational capabilities of complex syntactic structures.

The most active are connecting educations with conjunctions but. The joining structures with connectors and, yes, are less active. Irregularly, we consider joining sentences with conjunction however.

Key words: additional construction, complete additional sentence, incomplete additional clause, coordinate conjunctions, principal clause.

Постановка проблеми. Дослідження проблем семантики в сучасному мовознавстві постійно привертає увагу мовознавців, зокрема до питань експресивного синтаксису. У сучасній українській лінгвістиці досі залишається невирішеною проблема виокремлення та покваліфікування приєднувальних конструкцій, простежуються різні підходи щодо структурно-семантичних особливостей парцелятивних та приєднувальних конструкцій. Науковий аналіз таких структур засвідчив, що окремі науковці такі поняття, як «парцеляція» й «приєднування» не розмежовують $[3 ; 7]$, тоді як деякі із них чітко виокремлюють $[1-4 ; 6 ; 8]$.

Приєднувальні структури аналізують переважно на матеріалі художніх та публіцистичних текстів, тоді як у текстах конфесійного стилю природа таких 
речень не досліджувалася. Такі речення становлять окрему ланку в загальній системі стилістичних виражальних засобів мовлення в художньому тексті, публіцистичному і віднедавна в конфесійному. Особливості будови приєднувальних речень уможливлює їхнє використання як засобу комунікативної чи стилістичної мети.

Досить чітке визначення терміна «приєднування» пропонує В. Богатько: «Приєднування - це семантико-граматична категорія, що має власну семантику (значення додаткового повідомлення) і власну граматичну форму вираження цієї семантики (спеціальні сполучники, сполучні слова)» [2, с. 120].

Аналіз наукових досліджень і публікацій. Підтримуючи погляди К. Г. Городенської, А. П. Загнітка, Н. М. Івкової, В. В. Богатько, Л. І. Конюхової та інших українських лінгвістів, вважаємо, що приєднувальна структура уточнює, конкретизує, деталізує чи означує один або декілька елементів основного речення. У лінгвістиці приєднування тлумачать як конструкцію, що уточнює, конкретизує, деталізує чи означує один або декілька елементів головного речення $[2 ; 4 ; 5 ; 7 ; 8]$. Сурядні сполучники єднальної та протиставної семантики в таких конструкціях виступають основними засобами приєднувальних семантико-синтаксичних відношень.

У пропонованому дослідженні ставимо за мету 3'ясувати особливості використання окремих єднальних та протиставних сполучників як засобів зв'язку приєднувальної структури 3 головним реченням у текстах конфесійного стилю.

Виклад основного матеріалу. Сурядні сполучники - це функціонально цілісні одиниці. Вони виконують сполучну функцію між головним реченням і приєднувальною структурою та виражають певний тип семантико-синтаксичних відношень між структурними компонентами. Приєднувальне речення має відносно самостійний зміст, але виникає як додаткове повідомлення, яке сполучники не поєднують в одне ціле, а приєднують до попереднього [6, с. 23]. За нашими дослідженнями, найактивніше у текстах конфесійного стилю функціонують приєднувальні конструкції зі сполучниками але та однак, на відміну від таких речень у художньому та публіцистичному стилях, де функціонування таких структур менш активне. Напр.: «Bпаде побіч тебе тисяча, $і$ десять тисяч праворуч тебе, до тебе ж не приблизяться. Однак ти очима споглянеш і відплату грішників побачиш» (Псалом 90). Із метою підсилення стилістичного ефекту та експресії в текстах релігійної тематики спостерігаємо синтаксичні утворення, де приєднувальний компонент утворює абзац. Напр.: «Сповідь - ие невід'ємний засіб повторення та перевиховання. Однак мусимо погодитись із тим, щзо невдачі й трудноші, з якими ми зазвичай змагаємося, відразу не зникнуть» [16].

Широкий функціональний діапазон у текстах конфесійного стилю і повних приєднувальних структур зі сполучником але. Центральне місце посіли складнопідрядні приєднувальні речення (як і в художніх текстах та публіцистиці). Підрядні компоненти таких конструкцій є детермінантного або прислівного характеру і перебувають у постпозиції щодо основної для них частини. Напр.: «Владико $і$ Суддя мій, не відкинь мене від лиия Твого. Але всесильною Твоєю рукою Сам мене з Себе наверни $і$ на шлях істинного покаяння направ, щоб віднині поклав спасіння мого початок» [12].
Приєднувальні складносурядні структури вирізняються дещо узуснішим вживанням, ніж приєднувальні складнопідрядні. Напр.: «Не осуджуйте, не завидуйте, моліться за своїх неприятелів. Знаю, що ви не здатні ие робити. Але просіть кожного дня моє Серие і Серие мого найдорожчого Сина, а ми дамо вам Божу ласку...» [10].

Дедалі ширшого вжитку набули багатокомпонентні приєднувальні конструкції конфесійних текстів. Переважно це приєднувальні структури з різними видами підрядності. Напр.: «... хто ще не забув дї̈ молитви. Але ü той, хто має дієву молитву, - під час поруху тілесних пристрастей... пристрастей лютих і тяжких, часто встає, щуоб простягти руки для помочі...» [13].

Сучасні тексти релігійної тематики вирізняються активним функціонуванням структур, початковим елементом сурядної частини яких у функції приєднування виступають єднальні сполучники $\boldsymbol{i}(\check{\boldsymbol{u}})$. Граматичний зв'язок між основним реченням та повною приєднувальною структурою досить слабкий, адже приєднувальна конструкція із формально-граматичного боку $\epsilon$ окремим завершеним висловленням.

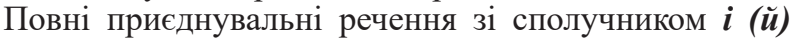
поділяємо на дві великі групи:

1) Повні приєднувальні конструкиї, щчо виражають часові відношення, вносячи відтінок одночасності або часової послідовності подій. Приєднувальне речення, що містить додаткову інформацію, дозволяє проаналізувати певну подію в часі. Напр.: «Ти дозволив щцасливо пережити ицю ніч і збудив мене до подальшого життя, щоб у ньому Тебе величати та вірно Тобі служити. І хочу иче робити до останньої хвилі мого життя» [12];

2) Повні приєднувальні конструкиії, щзо виражають причинно-наслідковий зв'язок. Головними при цьому виступають пауза й інтонація, які дещо «окреслюють» приєднувальне речення, що яскраво демонструє свою самостійність та інтонаційне відокремлення. Напр.: «... клопочися про мене і мою родину, шуоб ми зберегли нашого Бога в своїх сериях. I тим собі заслужили спасенного Всевишнього посередництва у нашій потребі...» [13].

Менш активно у текстах конфесійного стилю представлені приєднувальні речення з єднальним сполучником ma. Виступаючи виразником приєднувальних семантико-синтаксичних відношень, поєднує повну приєднувальну конструкцію, що виражає додаткову атрибутивну, об'єктну, адвербіальну семантику, з основним. Напр.: «Коли людина скоює гріх, то ставиться до Бога так, наче може без Нього обійтися, підводячи себе під вимоги справедливості. Та Бог своїм милосердям починає все заново, можна навіть сказати, Він наполягає на тому, що перемогла любов» [16].

Сурядні сполучники $\boldsymbol{i}(\check{u})$, але, приєднуючи додаткове повідомлення до основного, дедалі ширше використовуються в релігійних текстах. Проте вони неоднакові за своїми функціональними можливостями. Так, сполучник $\boldsymbol{i}(\check{\boldsymbol{u}})$ активно приєднує повні та неповні прості речення атрибутивної, адвербіальної та дещо рідше об'єктної семантики до основного, тоді як сполучник aлe виявляє тенденцію до приєднання складних синтаксичних утворень із різного виду ускладненнями.

Окрему позицію обіймають приєднувальні конструкції питального характеру зі сполучниками $\boldsymbol{a}$ й але. Такі речення сприяють ще більшій експресії висловлювання, відображають певну ділянку дійсності в реченні або з'ясовують якийсь істотний момент відповідної ділянки дійсності. 
Найактивніше використовують приєднувальні структури питально-риторичного та власне питального характеру. Напр.: « ... про ице знаєш. Але чи Тобі відомо, що буде завтра?»; «А наша відповідальність за структури, в яких ми живемо... А щьо сказати про байдужість християнина щьодо політичних поглядів?» [16].

Сурядний сполучник $\boldsymbol{a}$, виступаючи виразником приєднувальних семантико-синтаксичних відношень, вирізняється поступовим розширенням щодо сфери свого використання (як і в художніх текстах та публіцистиці). Він слугує для послідовного переходу від однієї думки до іншої, сприяє встановленню зв'язків між явищами в реченні. Напр.: « ... відійти иьому ворогові i його впливам від мене $i$ від всіх мойх ближніх $і$ йти на дно пекла до того, щзо його послав. А також прошу захисту для себе на добу $і$ на иіле життя» [14].

Яскраво виокремлюються структури, в яких сполучник $\boldsymbol{a}$, виражаючи приєднувальні семантико-синтаксичні відношення, приєднує предикативну частину до однієї або кількох попередніх, завершаючи послідовний виклад думок, сурядним зв'язком. Напр.: «...віддали всякі злі нечисті сили, щчо діють за намовою диявола. А якщо задумане зло почало свою дію, зупини його...» [10], «...нехай Твій Отеиь буде добрий до нас. А ми -добрими до нього» [9].

Таким чином, сполучник $\boldsymbol{a}$ вносить у речення розмовний відтінок. Зокрема, дедалі ширшого вжитку набувають приєднувальні багатокомпонентні речення 3 цим сполучником. Активні синтаксичні процеси, які відбуваються у сучасній мовленнєвій системі, стали проникати і в тексти конфесійного стилю. Так, приєднувальна багатокомпонентна структура постає одним iз найпродуктивніших синтаксичних засобів актуалізації елементів прагматично-комунікативного рівня мовленнєвої системи. На нашому матеріалі зафіксовані багатокомпонентні приєднувальні конструкції зі сполучником $\boldsymbol{a}$. Напр.: «Я з вами $i$ заступаюся перед Богом за всіх вас. А ви не бійтеся, бо той, хто молиться, не боїться зла і не має ненависті в сериіџ [17]; «... зміна поглядів щзодо поступу в житті. А й справдi, котрогось дня ми справді починаємо врешті відчувати, щио від християнина вимагається відразу все, і шео християнське життя не полягає в тому, щоб здобувати кількісні досягнення чи виконувати низку різних обов'язків, про які можна пізніше забути, а про те, щчоб усі иі обов'язки виконувати щчораз ліпше» [16].

Аналіз фактичного матеріалу засвідчив, що 3-поміж приєднувальних сурядних сполучників, зокрема nроте, зате, у приєднувальних структурах зазвичай використовують сполучник проте, хоча активніше сполучник проте функціонує в публіцистичних текстах. У релігійних текстах він $є$ нерегулярним. Приєднувальні речення із цим сполучником бувають атрибутивної, об'єктної або адвербіальної семантики. Напр.: «Як взагалі можна говорити про поступ, коли треба постійно повторювати одне і те ж? Проте саме так $i \epsilon, i$, може, саме сповідь схилить нас до радикальноі зміни поглядів щзодо поступу в житті» [16].

Сполучник зате приєднує зазвичай неповне атрибутивне, об'єктне чи адвербіальне речення, надаючи виразного протиставно-компенсувального значення. Напр.: «Гріх порушує порядок речей. Зате Божа любов віднаходить новий порядок» [16].

Висновки. Отже, приєднувальні конструкції із сурядними сполучниками єднальної та протиставної семантики активно використовуються в текстах конфесійного стилю для увиразнення кожного відрізка повідомлення. Певна комунікативна автономність підкреслює зміст висловлення, покращує сприйняття інформації. Крім того, приєднування розширює синтаксичні, стилістичні та інформаційні можливості складних синтаксичних структур.

Найактивніше виявляються приєднувальні утворення зі сполучниками $\boldsymbol{a}$, $\boldsymbol{a} \boldsymbol{л}$ й представлені приєднувальні конструкції зі сполучниками $\boldsymbol{i}$ й $\boldsymbol{m a}$. Нерегулярними вважаємо приєднувальні речення зі сполучниками зате та проте.

\section{СПИСОК ВИКОРИСТАНОЇ ЛІТЕРАТУРИ}

1. Белошапкова В. А. Сложное предложение в современном русском языке (некоторые вопросы теории) / В. А. Белошапкова. - М. : Просвещение, 1967. - 160 с.

2. Богатько В. В. Явища еліпсису в слові сучасної української публіцистики : дис. ... канд. філол. наук : спец. 10.02.01 / В. В. Богатько ; Вінницький держ. пед. ун-т ім. М. Коцюбинського. - Вінниця, 2005. - 175 с.

3. Ванников Ю. В. Синтаксис речи и синтаксические особенности русской речи / Ю. В. Ванников. М. : Русский язык, 1979. - 296 с.

4. Городенська К. Г. Граматичний словник української мови: сполучники / К. Г. Городенська. - Херсон : Вид-во ХДУ, 2007. - 340 с.

5. Городенська К. Г. Граматичний словник сполучників української мови (концепція та принципи укладання) / К. Г. Городенська // Українська мова. 2005. - № 2. - С. 28-35.

6. Жайворонок В. В. Приєднувальні сполучники у структурі складного речення / В. В. Жайворонок // Мовознавство. - 1975. - № 5. - С. 67-74.

7. Загнітко А. П. Теоретична граматика української мови: синтаксис : монографія / А. П. Загнітко. Донецьк : ДонНУ, 2001. - 662 с.

8. Івкова Н. Структурна та функціонально-семантична специфіка приєднувальних конструкцій у текстах публіцистичного стилю / Н. Івкова // Актуальні проблеми сучасної філології. Мовознавчі студії : зб. наук. праць Рівненського держ. гум. ун-ту. - Рівне : РДГУ, 2005. - Вип. 13. - С. 53-56.

9. Клич до Бога [Електронний ресурс]. URL: http://medjugorje.com.ua/duchovnist/1594-poklyk-doboga.html (дата звернення: 20.05.2019).

10. Молитва до Господа Ісуса розіп'ятого [Електронний ресурc]. URL: http://mizoch-hram.com.ua/molytvy/ molytvy-do-gospoda (дата звернення: 16.04.2019).

10. Молитви до Богородиці 3 Меджугор'я. Львів, 2013. - 72 с.

12. Молитва до Ісуса Христа [Електронний реcypc]. URL: http://blyzhchedoboga.com.ua/molitva-dogospoda-isusa/ (дата звернення: 18.05.2019).

13. Молитва на дев'ять вівторків до святої Марти [Електронний ресурс]. URL: https://molytva.at.ua/ index/dev39jatnicja_do_svjatoji_marti/0-39 (дата звернення: 20.05.2019).

14. Молитва на відігнання особистого ворога [Електронний ресурс]. URL: http://medjugorje.in.ua/ books/molitvennik-1.pdf (дата звернення: 10.06.2019).

15. Самовичитка [Електронний ресурс]. URL: http://ua.convdocs.org/docs/index-96640.html?page $=14$ (дата звернення: 10.06.2019).

16. Усе про сповідь. - Львів : Свічадо, 2017. - 168 с.

17. Хреснадорога. ХІІІ стація [Електронний ресурс]. URL: http://radiomaria.org.ua/hresna-doroga-za-dushi-vchistilishi-audiotekst-3903 (дата звернення: 10.06.2019).

Дата надходження до редакиї: 21.06.2019 p. 